\title{
Abbreviations of the works of Rainer Forst
}

CoJ Contexts of Justice: Political Philosophy Beyond Liberalism and Communitarianism, trans. J.M.M. Farrell (Berkeley: University of California Press, 2002)

JUC Justification and Critique: Towards a Critical Theory of Politics, trans. C. Cronin (Cambridge, MA: Polity Press, 2014)

JDRJ Justice, Democracy and the Right to Justification: Rainer Forst in Dialogue (London: Bloomsbury, 2014)

N\&P Normativity and Power: Analyzing Social Orders of Justification, trans. C. Cronin (Oxford: Oxford University Press, 2017)

RtJ The Right to Justification: Elements of a Constructivist Theory of Justice, trans. C. Cronin (New York: Columbia University Press, 2011)

TiC Toleration in Conflict: Past and Present, trans. C. Cronin (Cambridge: Cambridge University Press, 2013) 
Rainer Forst - 9781526148339

Downloaded from manchesterhive.com at 04/26/2023 11:26: 09AM 